\title{
Fluorosis and Dental Caries in the Hydrogeological Environments of Southeastern Communities in the State of Morelos, Mexico
}

\author{
Gricelda G. Varela-González ${ }^{1}$, Alvaro García-Pérez ${ }^{2}$, Rafael Huizar-Alvarez ${ }^{1}$, \\ Maria Esther Irigoyen-Camacho ${ }^{3 *}$, Maria M. Espinoza-Jaramillo ${ }^{1}$ \\ ${ }^{1}$ Departamento de Geología Regional, Instituto de Geología, Universidad Nacional Autónoma de México, Mexico City, Mexico; \\ ${ }^{2}$ División de Estudios de Posgrado e Investigación, Facultad de Odontología, Universidad Nacional Autónoma de México, Mexico \\ City, Mexico; ${ }^{3}$ Departamento de Atención a la Salud, Universidad Autónoma Metropolitana Xochimilco, Mexico City, Mexico. \\ Email: huizar@unam.mx, agarcia160@hotmail.com, *meirigo@correo.xoc.uam.mx
}

Received May $26^{\text {th }}, 2013$; revised June $27^{\text {th }}, 2013$; accepted July $24^{\text {th }}, 2013$

Copyright (C) 2013 Gricelda G. Varela-González et al. This is an open access article distributed under the Creative Commons Attribution License, which permits unrestricted use, distribution, and reproduction in any medium, provided the original work is properly cited.

\begin{abstract}
Objectives: 1) To identify the hydrogeological characteristics and fluoride ( $\mathrm{F}^{-}$) concentration in drinking water in the southeast of the state of Morelos, Mexico, and 2) to estimate the association between the prevalence and severity of fluorosis, dental caries, and water $\mathrm{F}^{-}$concentration. Methods: A hydrogeological model was developed to determine the vertical distribution of lithostratigraphic units, rocks' hydraulic conductivities, and groundwater flow characteristics. A total of 649 schoolchildren from two communities received oral examinations. One community was located in an area with $0.75 \mathrm{mg} \mathrm{F}^{-} / \mathrm{L}$ in the water supply and the other in an area with $1.6 \mathrm{mg} \mathrm{F}^{-} / \mathrm{L}$. Fluorosis was assessed using the Thylstrup \& Fejerskov Index (TFI) and the dental caries were assessed with the decayed, missing, and filled teeth (DMFT) index. The region groundwater was extracted from an inter-granular aquifer consisting of volcano clasts of intermediate volcanic chemical composition. Results: Oral examinations showed that $32.35 \%$ of the children had severe

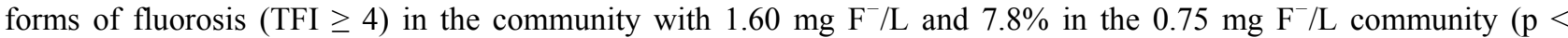
$0.0001)$. DMFT $=0.53( \pm 1.28)$ and $0.42( \pm 0.95)$ in the community with $1.60 \mathrm{mg} \mathrm{F}^{-} / \mathrm{L}$ and $0.75 \mathrm{mg} \mathrm{F} / \mathrm{L}$, respectively $(\mathrm{p}$ $=0.2259)$. Conclusions: The increasing extraction of underground water was associated with deeper water flows and higher $\mathrm{F}^{-}$concentration. In the community with high $\mathrm{F}^{-}$concentration, a third of the children showed objectionable levels of fluorosis. Adequate groundwater management actions are required to reduce fluorosis risk.
\end{abstract}

Keywords: Fluoride; Drinking Water; Fluorosis; Dental Caries; México

\section{Introduction}

The constant, worldwide increase in population results in a decrease in the volume of drinking water available per capita. In some places, the water withdrawn has a tendency towards chemical and biological degradation. The consumption of water provided in urban water systems, even in developed countries, sometimes can produce diseases that affect the health of large population groups [1]. Children are more susceptible than adults to diseases related to the consumption of poor water quality. To protect their health, it is not enough to provide them water; it is paramount to ensure the best possible water quality [2].

${ }^{*}$ Corresponding author.
Approximately $99 \%$ of fluoride $\left(\mathrm{F}^{-}\right)$in the human body is found in bones and teeth [3]. High water $\mathrm{F}^{-}$concentrations produce skeletal and dental fluorosis [4]. Nevertheless, in adequate amounts, $\mathrm{F}^{-}$prevents dental caries. Thus, since the 1950 s, water fluoridation has been promoted as a public health measure. The limits recommended by the World Health Organization (WHO) for the $\mathrm{F}^{-}$concentration in water range from 0.7 to $1.2 \mathrm{mg}$ $\mathrm{F}^{-} / \mathrm{L}$, depending on weather conditions and the amount of water consumed per day in the region [5].

Currently, hundreds of millions of people around the world benefit from fluoridated water. In the United States, Canada, Brazil, Argentina, Colombia, Chile, Australia, New Zealand, Malaysia, Israel, cities like Hong Kong and Singapore [6], and some countries of the European 
Community, water fluoridation is one of the main measures established to prevent dental caries [7]. In Mexico, as in many countries in Latin America, salt fluoridation programs have been implemented as public health measures to prevent dental caries. According to the Mexican standard, the amount of fluorine that is added to the salt varies between 200 and $250 \mathrm{mg} \mathrm{F}^{-} / \mathrm{kg}$ salt [8].

In many countries, a decline in dental caries has been accompanied by an increase in the prevalence of dental fluorosis [9]. Groundwater is an important source of $\mathrm{F}^{-}$; its presence is mainly related to the existence of acid and intermediate rocks. Fluoride concentration in groundwater varies according to the time of the interaction between water and rock, the depth at which the water flows, and underground temperature, as $\mathrm{F}^{-}$concentration increases in geothermal terrains [10]. In areas with endemic fluorosis, $\mathrm{F}^{-}$in groundwater is frequently the main cause of this disease and deeper water often shows higher $\mathrm{F}^{-}$concentrations than shallow wells show [13].

Dental fluorosis occurs during tooth formation; ingestion of $\mathrm{F}^{-}$during the first four years of life is critical to the development of fluorosis in the aesthetically significant permanent teeth. Dental fluorosis is the result of alterations in mineralization of the tooth; in enamel, $\mathrm{F}^{-}$is present in the crystalline structure. Fluorosis is accompanied by a poor removal of the enamel's protein matrix and an increase in the size of the enamel's pores [11]. Clinically, this condition is observed as whitish spots at the initial level; teeth with higher fluorosis severity show brown and dark brown areas, and pitting of enamel becomes visible. When more severe loss of enamel is present, tooth morphology is altered, producing an aesthetic and functional deterioration of the dentition [11,12].

In a systematic review of 214 studies, Mc Donagh et al. analyzed the safety and efficacy of fluoridation of drinking water. Their review identified a decrease in the dental caries prevalence and an increase of dental fluorosis [13].

Groundwater quality, and in this particular case $\mathrm{F}^{-}$ content, is related to the chemical composition of the minerals found in the aquifer. In Mexico, a large variation in groundwater $\mathrm{F}^{-}$content has been identified $(0.001$ $\mathrm{mg} / \mathrm{L}$ to $25 \mathrm{mg} / \mathrm{L}$ ) [14]. High water $\mathrm{F}^{-}$concentrations have been found mainly in the northern and central states of the country; these regions frequently show a high prevalence of dental fluorosis [15], and in some communities dental fluorosis severity is a public health concern. In addition, there are reports on the occurrence of fluorosis in some regions in the Midwest of Mexico [16], as in the state of Morelos [17].

Identifying areas with fluorosis could help control this condition through oral health educational programs and hydrogeological interventions aimed at reducing $\mathrm{F}^{-}$in drinking water. Also, information on oral health condi- tions, considering both caries and fluorosis, could help policy makers and dental practitioners implement programs to prevent dental caries and reduce the risk of dental fluorosis.

From this perspective, the objectives of this study were: 1) to identify the hydrogeological characteristics and water $\mathrm{F}^{-}$concentration in communities at the southeast of Morelos state, Mexico, and 2) to estimate the association among fluorosis status, dental caries, and water $\mathrm{F}^{-}$ concentration in schoolchildren living in two communities with different $\mathrm{F}^{-}$concentration in the supplied groundwater.

\section{Methodology}

This cross-sectional study's research protocol was reviewed and approved by the Research Committee of the Biological and Health Sciences Division of the Universidad Autónoma Metropolitana-Xochimilco, Mexico, and ethical aspects of the project were considered.

\subsection{Study Region}

The study was conducted in the municipality of Villa de Ayala in the Morelos state, which, from the geomorphological perspective, is located on a plain with an elevation of $1200 \mathrm{~m}$ above sea level (MASL); having an undulating topography with small hills, it is drained by deep ravines that run from northeast to southwest. A hydrogeological model was developed to determine the spatial and vertical distribution of lithostratigraphic rock units defining their petro-physical and hydraulic properties as well as their prevailing groundwater flow characteristics. Groundwater samples to determine the content of anions, cations, and trace elements in wells label P-1 and P-2 were collected (Figure 1). Eh, pH, electrical conductivity, and temperature values were recorded during both field and laboratory tests.

\subsection{Laboratory Analysis}

The content of $\mathrm{HCO}_{3}^{-}$and $\mathrm{CO}_{3}^{-}$were analyzed by the titration method according to American Public Health Association (APHA) standard methods [18]. The content of other anions was determined by liquid chromatogramphy. Metals in acidified, filtered samples were analyzed by atomic absorption spectrometry and Inductively Coupled Plasma Mass Spectrometry (ICP-MS). The $\mathrm{F}^{-}$content was obtained by chromatography and an ion-selective electrode $\left(\operatorname{Orion}^{\mathrm{TM}}\right)$. All samples were analyzed in duplicate.

\subsection{Study Group}

This study included children between 8 and 12 years of 


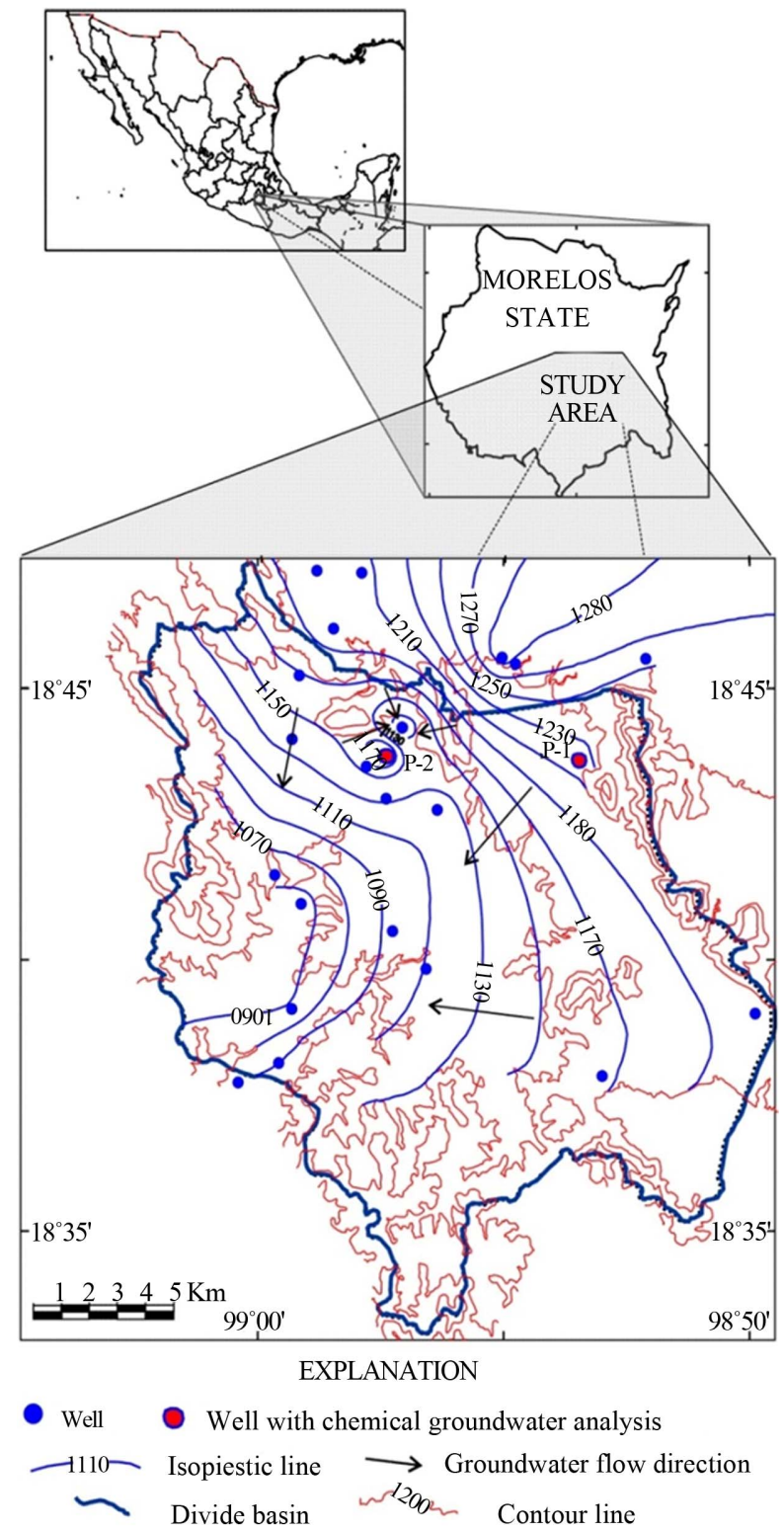

Figure 1. Location and groundwater flow direction of the study area of the state of Morelos, México.

age attending two public elementary schools located in the municipality of Villa de Ayala, Morelos. The $\mathrm{F}^{-}$concentration in water wells (P-1 and P-2) in these communities was $0.75 \mathrm{mg} \mathrm{F}^{-} / \mathrm{L}$ and $1.60 \mathrm{mg} \mathrm{F}^{-} / \mathrm{L}$, respectively.

Schoolchildren inclusion criteria were to have been born in the selected community and not to have changed residence for more than six months. The parents of the selected schoolchildren were informed about the study's purpose and the procedures that would be undertaken in the participating children, and $96.9 \%$ of the parents signed a letter of consent. Parents also completed a questionnaire on their children's places of birth, history of residence, source of drinking water, and oral hygiene habits. The study group included 206 schoolchildren living in the community with $0.75 \mathrm{mg} \mathrm{F}^{-} / \mathrm{L}$ and 443 living in the community with $1.60 \mathrm{mg} \mathrm{F}^{-} / \mathrm{L}$.

\subsection{Oral Cavity Examination}

During inspection of the oral cavities of the participating children, infection control standards were followed [19]. The instruments used in the oral exams were No. 5 mirrors and WHO-type probes. For the dental fluorosis diagnosis, all erupted permanent teeth were assessed according to the Thylstrup-Fejerskov Index (TFI) criteria. Higher scores in this index indicate higher damage in the tooth structure [20]. The assessment of dental caries was performed considering the WHO criteria to obtain the decayed, missing, and filled permanent teeth (DMFT) index [21]. Each examination was conducted with the child placed in a supine position on a table; lighting was provided by a white-light lamp, and teeth were cleaned and dried before examination. Previously, the presence of plaque was detected through a simplified oral hygiene index, considering the presence of dental debris (Oral Hygiene Index-Simplified). A standardized dentist with experience in fieldwork conducted all the oral exams. Levels of reliability of kappa $=0.89$ for the TFI and 0.90 for the presence of dental caries were obtained.

\subsection{Statistical Analysis}

To assess the integrity of data and to describe the study group, an exploratory analysis of the selected variables was conducted. Based on the results of the TFI, Pearson's $\mathrm{X}^{2}$ tests were performed between categories of and the variables were studied. Non-parametric statistical tests (Kruskal Wallis Tests) were applied to examine the differences in age and level of fluorosis in the study areas. A logistic regression model was generated to identify the association between the presence of fluorosis (TFI $\geq 1$ ) and the $\mathrm{F}^{-}$concentration in water, controlling for age and gender; the odds ratio (OR) was obtained and its $95 \%$ confidence interval $(95 \% \mathrm{CI})$. A linear regression model was implemented to study the association between the caries index and the $\mathrm{F}^{-}$concentration in water, controlling for age, gender, and oral hygiene index. The significance level for hypothesis testing was $\mathrm{p}<0.05$. Data were analyzed using STATA V.10.

\section{Results}

\subsection{Hydrogeology}

The lithostratigraphic column in the study region, from bottom to top, consists of marine sedimentary rocks, shale, limestone, and dolomite, all comprising the Morelos Formation, and a limestone sequence in thick layers, 
laminated limestone, and clastic limestone, all forming the Cuautla Formation. These rock units outcrop at the north, east, and west of the plain, and they are covered by Tertiary continental clastic deposits of the Balsas Group and by volcanic rocks of the Ixtlilco Group [22]. In the northeast and east outcrops of granodiorite, quartz syenite and Tertiary have been described. In the south and southeast of the plain, there are ignimbrites and rhyolites of Tertiary age outcrop that belong to the Tlaica Formation [22]. In the center and south of the plain, undifferentiated volcanic rocks (andesite, basalt, dacite, and diorites) of the Ixtlilco Group are present. Finally, underneath the plain, a filling has been observed consisting of clastic, conglomerate, lahars, breccia, gravel, sand, and clay of the Quaternary age.

Based on the nature of the rock units, they were grouped into a granular unit and a fissured hard rock unit. Both units are inter-bedded; the top unit is mainly granular passing transitionally to the fissured. Currently, the water supply for the population is obtained from the granular unit in the communities studied. The water-table configuration showed the presence of a local drawdown cone, probably indicating that groundwater flows mainly from the northeast to the southwest (Figure 1); suggesting that a significant groundwater inflow is horizontal input from outside the region.

\subsection{Groundwater Chemistry}

Chemical analyses of extracted groundwater from wells P-1 and P-2 (Figure 1) show that ions, in order of abundance, were: $\mathrm{HCO}_{3}^{-}, \mathrm{Na}^{+}, \mathrm{Ca}^{2+}, \mathrm{Mg}^{2+}$, and $\mathrm{SO}_{4}^{2-}$ (Table 1). There were two hydrochemical facies: 1) $\mathrm{HCO}_{3}-\mathrm{Na}-\mathrm{Ca}$ and 2) $\mathrm{HCO}_{3}-\mathrm{Ca}-\mathrm{Na}$. The hydrochemical facies agreed with the geological environment; through

Table 1. Groundwater chemical composition of the wells anlyzed in this study (P1 and P2), values in meq/L, Temperature in ${ }^{\circ} \mathrm{C}$.

\begin{tabular}{ccc}
\hline Well & P1 & P2 \\
\hline Water temp & 25.3 & 26.4 \\
$\mathrm{Ca}^{2+}$ & 7.75 & 4.75 \\
$\mathrm{Mg}^{2+}$ & 1.25 & 1.07 \\
$\mathrm{Na}^{+}$ & 7.57 & 6.32 \\
$\mathrm{~K}^{+}$ & 0.57 & 0.31 \\
$\mathrm{HCO}_{3}^{-}$ & 9.86 & 8.04 \\
$\mathrm{Cl}^{-}$ & 1.72 & 2.54 \\
$\mathrm{SO}_{4}^{2-}$ & 1.9 & 1.36 \\
$\mathrm{NO}_{3}^{-}$ & 1.04 & 0.03 \\
$\mathrm{~F}^{-}$ & 0.75 & 1.6 \\
\hline
\end{tabular}

groundwater flows consisted of volcanic rocks of intermediate to acid chemical composition, the main minerals of which were $\mathrm{Na}, \mathrm{Ca}$, and plagioclase.

\subsection{Fluoride in Groundwater}

Groundwater obtained in well P-1 had $0.75 \mathrm{mg} \mathrm{F}^{-} / \mathrm{L}$ and a temperature of $25.3^{\circ} \mathrm{C}$, while water in well P-2 had 1.60 $\mathrm{mg} \mathrm{F}^{-} / \mathrm{L}$ and was $26.4^{\circ} \mathrm{C}$ (Table 1) In the $\mathrm{P}-1$ well, water is withdrawn $10 \mathrm{hrs} / \mathrm{day}$, while in the P-2, water is withdrawn $22 \mathrm{hrs} /$ day or more. The main groundwater inflow comes from north and northeast, from and beyond the studied region; this suggests two $\mathrm{F}^{-}$sources: a) an intermediate flow located north-northeast and b) a local flow indicated by the low temperature.

\subsection{Dental Fluorosis}

Oral examination was completed in 649 children; the average age was $10.18( \pm 1.27)$ years. The percentage of females was $48.6 \%$ (316), and 51.4\% (333) were males. The average age for girls was $10.19( \pm 1.27)$ years, while for boys it was $10.17( \pm 1.26)$ years $(\mathrm{p}=0.8738)$.

In the study group, the prevalence of dental fluorosis $(\mathrm{TFI} \geq 1)$ was $68.3 \%$ and $(\mathrm{TFI} \geq 4)=24.5 \%$. By gender, the prevalence of dental fluorosis in TFI1 was $56.3 \%$ in girls and $55.6 \%$ in boys $(\mathrm{p}=0.8427)$, in TFI2 it was $55.0 \%$ for girls and $56.2 \%$ in boys $(\mathrm{p}=0.7794)$, and in TFI3 it was $44.9 \%$ for girls and $53.5 \%$ in boys ( $\mathrm{p}=$ $0.0301)$. TFI $\geq 4$ correspond to categories in which the entire surface of the tooth is affected, and the prevalence of TFI4 fluorosis by gender was $20.9 \%$ in girls and $27.3 \%$ in boys $(\mathrm{p}=0.0392)$.

The prevalence of dental fluorosis $(\mathrm{TFI} \geq 1)$ in the group of 8 - 9 years old was $64.4 \%$, and in the group of $10-12$ years old it was $68.9 \%(\mathrm{p}=0.1777)$; for $\mathrm{TFI} \geq 4$, it was $17.3 \%$ for the group of $8-9$ years of age and $27.6 \%$ in the group of 10 - to 12 -year-olds $(\mathrm{p}=0.0055)$.

\subsection{Dental Fluorosis by Community}

In the area where the water $\mathrm{F}^{-}$concentration was 0.75 $\mathrm{mg} \mathrm{F}^{-} / \mathrm{L}$, the prevalence of dental fluorosis was lower than $(62.62 \%)$ in the area with $1.60 \mathrm{mg} \mathrm{F}^{-} / \mathrm{L}(70.88 \%)$, $(\mathrm{p}<0.0444)$ (Table 2). The logistical regression model showed an OR of 1.43 (95\% CI 1.03, 2.06), controlling for age $(\mathrm{p}=0.0365)$ and sex $(0.3856)$.

Figure 2 shows the frequency of fluorosis according to the TFI by community. More advanced fluorosis categories showed significant differences between the two communities. For the town with the lowest water $\mathrm{F}^{-}$concentration, TFI $\geq 4$ was detected in $7.8 \%$ of the children; while in the town with the highest water $\mathrm{F}^{-}$concentration, $\mathrm{TFI} \geq 4$ was found in $32.3 \%$ of the participants $(\mathrm{p}<0.0001)$. 
Table 2. Prevalence of dental fluorosis and dental caries mean community children in southeast of the state of Morelos, México.

\begin{tabular}{ccccc}
\hline & $\begin{array}{c}\text { Community 0.75 mg } \\
\mathbf{F}^{-} / \mathbf{L}\left({ }^{\mathrm{a}} \mathrm{n}=206\right)\end{array}$ & $\begin{array}{c}\text { Community 1.60 } \mathbf{~ m g} \\
\mathbf{F}^{-} / \mathbf{L}(\mathrm{n}=443)\end{array}$ & \multirow{2}{c}{$\mathbf{p}$} \\
\hline $\begin{array}{c}\text { Dental } \\
\text { fluorosis }\end{array}$ & $\mathrm{TFI} \geq 1 \quad \begin{array}{c}\mathrm{n}=129 \\
(62.6 \%)\end{array}$ & $\mathrm{TFI} \geq 1 \quad \begin{array}{c}\mathrm{n}=314 \\
(70.8 \%)\end{array}$ & 0.0444 \\
Dental caries & $\begin{array}{c}\text { DMFT } \\
\text { Mean }\left({ }^{\mathrm{b}} \mathrm{sd}\right)\end{array}$ & $\begin{array}{c}\text { DMFT } \\
\text { Mean (sd) }\end{array}$ & \\
& $0.42( \pm 0.95)$ & $0.53( \pm 1.28)$ & 0.2259 \\
\hline
\end{tabular}

${ }^{a}$ : number of children, ${ }^{b}$ sd: standard deviation, ${ }^{c}$ p: p-value.

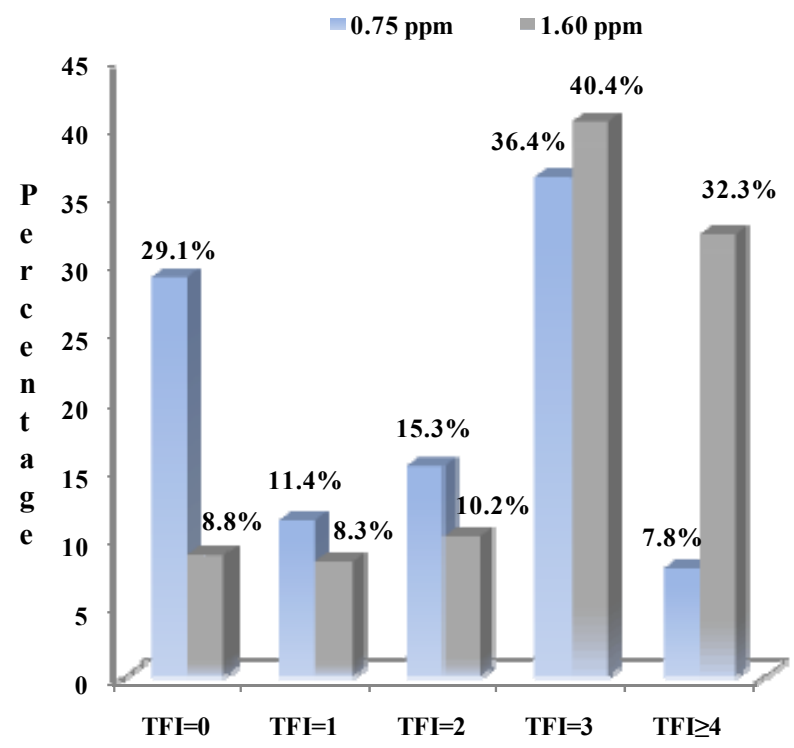

TFI: Thylstrup \& Fejerskov Fluorosis Index

Figure 2. Prevalence of dental fluorosis by locality in children aged 8 - 12 years of Morelos state, Mexico.

\subsection{Dental Caries}

The prevalence of dental caries (DMFT > 0) was 24.5\%. The average DMFT was $0.50( \pm 1.18)$. Nine-year-old children had an average DMFT of $0.25( \pm 0.70)$; and at age 12 , the mean DMFT was $0.77( \pm 1.70)$. Oral hygiene in $34.5 \%$ of students was poor $(\mathrm{OHI} \geq 2)$.

According to the regression model, the prevalence of dental caries by community was not statistically significant different; in the $0.75 \mathrm{mg} \mathrm{F} / \mathrm{L}$ community, the prevalence was $22.3 \%$, and it was $25.3 \%$ in the area with $1.60 \mathrm{mg} \mathrm{F}^{-} / \mathrm{L}(\mathrm{p}=0.3349)$, controlled by age $(\mathrm{p}=$ $0.0004)$, gender $(\mathrm{p}=0.2540)$, and oral hygiene $(\mathrm{p}=$ 0.0251 ). In addition, not statistically significant difference was detected in the dental caries index for the communities studied, (Table 2). The oral hygiene index was associated with caries experience-schoolchildren who had higher levels of plaque (IHOS $\geq 2$ ) showed higher DMFT $(0.65 \pm 1.46)$ than the children with better oral hygiene $(\mathrm{DMFT}=0.42 \pm 1.00,(\mathrm{p}=0.0192))$.

\section{Discussion}

\subsection{Groundwater}

The distribution of $\mathrm{F}^{-}$in the geological environment is heterogeneous among the different geological formations. Fluoride concentration in groundwater is considered to be originated mainly from geological sources [3], as is the case in the studied areas. The content of $\mathrm{F}^{-}$in the water wells studied was associated with its hydrogeological framework that geochemically tended to be alkaline.

Hydrochemical information suggests that groundwater inflow in the study region has two sources: one local flow from the immediate topographic area located to the north, east, and west of the area, and a second intermediate flow that arrives from the north and northeast, originnating from the external relief.

According to the hydrogeological characteristics of the study region, we propose that the main source of $\mathrm{F}^{-}$is released from the aquifer material (andesitic, rhyolitic volcanic rock) by chemical weathering, mainly by hydrolysis, once $\mathrm{F}^{-}$is in the solution; it is transported and dispersed by ground waters into extraction boreholes.

The literature suggests a close association between $\mathrm{Ca}^{2+}$ and $\mathrm{F}^{-}$concentrations in water [23-26]. In the region studied, the well with the lower $\mathrm{F}^{-}$concentration had a consistently higher content of $\mathrm{Ca}^{2+}$ and $\mathrm{HCO}_{3}^{-}$ compared to the well with the higher $\mathrm{F}^{-}$concentration. In addition, water temperature in the selected wells was greater than $25^{\circ} \mathrm{C}$, which was associated mainly with the influence of the geothermal gradient. This moderately hot groundwater suggested the existence of an intermediate flow system.

Carrillo-Rivera et al. studied the $\mathrm{F}^{-}$processes involved in the groundwater obtained for the city of San Luis Potosí (located in north-central Mexico). The authors concluded that the temperature had an important effect on the water content (geothermal heating), resulting in dissolution of primary minerals [27]. This indicated that the groundwater $\mathrm{F}^{-}$release mechanism in the study areas was through chemical weathering of igneous and sedimentary rocks.

The borehole with the higher water $\mathrm{F}^{-}$content in Morelos was essentially under continuous pumping conditions, while water obtained in the borehole with the lower $\mathrm{F}^{-}$concentration was operated about ten hours a day. This suggests that the high water extraction rate induces a vertical flow (from below), causing the well to capture a deeper flow system that has a significantly higher $\mathrm{F}^{-}$content relative to the other well. 


\subsection{Fluorosis and Dental Caries}

The TFI used in this study is recommended for regions with endemic fluorosis associated with $\mathrm{F}^{-}$intake in water above the recommended limit, as is the case in the study region [28]. TFI $>4$ involves loss of enamel [20]. The observed differences in the level of dental fluorosis were in the moderate to severe fluorosis forms; in the low $\mathrm{F}^{-}$ $\left(0.75 \mathrm{mg} \mathrm{F}^{-} / \mathrm{L}\right)$ community studied, less than $8 \%$ of the children were detected with fluorosis levels of TFI $\geq 4$, and over $30 \%$ of the children in the area with $1.60 \mathrm{mg}$ $\mathrm{F}^{-} / \mathrm{L}$ showed these fluorosis categories.

The relationship between fluorosis and high concentrations of $\mathrm{F}^{-}$in drinking water has been extensively reported in international studies, and there are reports in Mexican communities [29-31]. The recommended $\mathrm{F}^{-}$ limit for water intake, according to the Mexican Secretary of Health Regulation (NOM-127-SSA1-1994), is between 1.0 and $1.5 \mathrm{mg} / \mathrm{L} \mathrm{[32].} \mathrm{Water} \mathrm{concentrations}$ above $0.7 \mathrm{mg} \mathrm{F}^{-} / \mathrm{L}$ imply a ban on the use of fluoridated salt in the community [8]. Furthermore, to reduce the risk of dental fluorosis, in the United States the recommended limit for water fluoridation was adjusted in 2011, from a range of 0.7 to $1.2 \mathrm{mg} \mathrm{F}^{-} / \mathrm{L}$ to a general standard of 0.7 $\mathrm{mg} \mathrm{F}^{-} / \mathrm{L}$ in artificially fluoridated drinking water systems [33].

Although the hydrogeological framework suggests that a large portion of the Mexican territory is at risk of fluorosis, limited information is available on the prevalence of dental fluorosis in Mexico. Some studies report this condition in northern and central states of the country [34-37]. For this reason, five states are excluded from the salt fluoridation program [8]. The state of Morelos is not within these five states; therefore, the population receives fluoridated and iodized salt.

In a study on the prevalence of fluorosis in children and adolescents in the state of San Luis Potosí, located in an area with similar $\mathrm{F}^{-}$concentrations in drinking water as in the present study, a comparable prevalence of fluorosis was found [38]. In the instant study, the highest levels of TFI $(\geq 4)$ were observed in children aged 10 - 12 years old. They showed a higher prevalence of these fluorosis categories $(27.6 \%)$ than the 8- to 9-year-old children $(18.2 \%)$. Likewise, the regression model constructed suggested that both age and concentration of $\mathrm{F}^{-}$ in water were associated with the prevalence of dental fluorosis. This information is similar to that found in other studies showing that older age increases fluorosis severity in young population groups [39]. It is possible that the porous fragility of enamel that is present at high levels of fluorosis deteriorates with time as a result of occlusion forces, increasing the damage in the tooth structure [11]. Follow-up studies in endemic fluorosis areas aiming to identify dental changes over time are re- quired.

A comparison of the results of the communities studied confirmed that the number of cases showing more severe fluorosis forms increased with higher water $\mathrm{F}^{-}$ content. This suggests that, despite the multiple $\mathrm{F}^{-}$ sources available in these communities, the presence of $\mathrm{F}^{-}$in drinking water remains a major risk factor for the development of dental fluorosis. Health education activities in communities with high water $\mathrm{F}^{-}$concentration are essential and require the participation of parents to help them identify $\mathrm{F}^{-}$sources, thus reducing their children's ingestion of this agent, particularly in infants and young children at the stage of tooth formation.

Dental caries indices were low in the communities studied. However, the DMFT index only counts caries lesions that are already affecting the dentin; it does not consider less advanced lesions. Herein, no significant differences in dental caries indices were observed between the communities studied. The identification of similar or higher rates of dental caries in areas with high $\mathrm{F}^{-}$exposure, compared to areas where the water $\mathrm{F}^{-}$content is lower, has been previously documented $[17,40]$. This emphasizes the need to avoid excessive $\mathrm{F}^{-}$exposure in children, because high fluoride ingestion will not produce additional protection of dental caries. The $\mathrm{F}^{-}$dose received by the children in a community frequently has to be calculated at the local level according to water $\mathrm{F}^{-}$ sources, climate, altitude above sea level, the physiological characteristics of the groups involved, and other factors.

The main water $\mathrm{F}^{-}$sources in the study region come from volcanic rocks. By relating $\mathrm{F}^{-}$concentration in groundwater to the hydrogeological setting, it follows that $\mathrm{F}^{-}$concentration is associated with alkaline geochemical conditions dominant in the area.

The fluorosis prevalence was high in both communities studied. Children in these communities are exposed to multiple $\mathrm{F}^{-}$sources. A higher prevalence of severe forms of dental fluorosis was observed in the area with higher fluoride concentration $\left(1.60 \mathrm{mg} \mathrm{F}^{-} / \mathrm{L}\right)$ in the water supply.

To decrease the $\mathrm{F}^{-}$content in the water supply of these communities, two alternatives could be considered: 1) implement water treatment using existing processes; for example, lime softening, coagulation with aluminum sulfate, or activated alumina. These processes imply high water treatment costs and produce a toxic sludge, or 2) implement in situ fluoride control, analyzing the response of $\mathrm{F}^{-}$by lowering the water temperature [27]. The control of fluorosis in endemic areas requires a multidisciplinary approach and the support of the community. Health and water quality are inseparable aspects and are particularly important in children. 


\section{Acknowledgements}

This study was supported in part by the master and doctoral programs in Medical Sciences, Dentistry, and Health at the Mexico National Autonomous University (Universidad Nacional Autónoma de México, UNAM) and Metropolitan Autonomous University, Xochimilco (Universidad Autónoma Metropolitana, UAM-X).

\section{REFERENCES}

[1] J. M. Brunkard, E. Ailes, V. A. Roberts, V. Hill, E. D. Hilborn, G. F. Craun, A. Rajasingham, A. Kahler, L. Garrison, L. Hicks, J. Carpenter, T. J. Wade, M. J. Beach and J. S. Yoder-Msw, "Surveillance for Waterborne Disease Outbreaks Associated with Drinking Water, United States 2007-2008," MMWR Surveillance Summaries, Vol. 60, No. 12, 2011, pp. 38-68.

[2] Stockholm International Water Institute and United Nations Millennium, "Health, Dignity, and Development: What Will It Take?" Stockholm International Water Institute (SIWI) and United Nations Millennium Project, New York, 2005.

[3] L. Kaminsky, M. Mahony and J. Leach. "Fluoride: Benefits and Risk of Expose," Critical Reviews in Oral Biology \& Medicine, Vol. 1, No. 4, 1990, pp. 261-281.

[4] S. K. Jha, V. K. Mishra, D. K. Sharma and T. Damodaran, "Fluoride in the Environment and Its Metabolism in $\mathrm{Hu}-$ mans," Reviews of Environmental Contamination and Toxicology, Vol. 211, 2011, pp. 121-142. doi:10.1007/978-1-4419-8011-3_4

[5] C. Palmer and S. H. Wolfe, "Position of the American Dietetic Association: The Impact of Fluoride on Health," Journal of the American Dietetic Association, Vol. 105, No. 10, 2005, pp. 1620-1628. doi:10.1016/j.jada.2005.08.017

[6] B. Kargul, E. Caglar and I. Tanboga, "History of Water Fluoridation," Journal of Clinical Pediatric Dentistry, Vol. 27, No. 3, 2003, pp. 213-217.

[7] G. Pizzo, M. R. Piscopo, I. Pizzo and G. Giuliana, "Community Water Fluoridation and Caries Prevention: A Critical Review," Clinical Oral Investigations, Vol. 11, No. 3, 2007, pp.189-193. doi:10.1007/s00784-007-0111-6

[8] Norma Oficial Mexicana, NOM-040-SSA1-1993, "Bienes y Servicios. Sal Yodatada y Sal Yodatada Fluorurada. Especificaciones Sanitarias," Diario Oficial de la Federación, Secretaria de Salud, Mexico, 2003, pp. 1-27.

[9] S. M. Levy, "An Update on Fluorides and Fluorosis," Journal of the Canadian Dental Association, Vol. 69, No. 5, 2003, pp. 286-291.

[10] N. S. Rao. "High-Fluoride Groundwater," Environmental Monitoring and Assessment, Vol. 176, No. 1-4, 2011, pp. 637-645. doi:10.1007/s10661-010-1609-y

[11] T. Aoba and O. Fejerskov, "Dental Fluorosis: Chemistry and Biology," Critical Reviews in Oral Biology \& Medicine, Vol. 13, No. 2, 2002, pp. 155-170. doi:10.1177/154411130201300206
[12] A. Bardsen, "Risk Periods Associated with the Development of Dental Fluorosis in Maxillary Permanent Central Incisors: A Meta-Analysis," Acta Odontologica Scandinavica, Vol. 57, No. 5, 1999, pp. 247-256. doi:10.1080/000163599428652

[13] M. S. McDonagh, P. F. Whiting, P. M. Wilson, A. J. Sutton, I. Chestnutt, J. Cooper, K. Misso, M. Bradley, E. Treasure and J. Kleijnen, "Systematic Review of Water Fluoridation," BMJ, Vol. 321, No. 7265, 2000, pp. 855859. doi:10.1136/bmj.321.7265.855

[14] L. M. Del Razo, J. C. Corona, G. García-Vargas, A. Albores and M. E. Cebrián, "Fluoride Levels in Well-Water from a Chronic Arsenicism Area of Northern Mexico," Environmental Pollution, Vol. 80, No. 1, 1993, pp. 91-94. doi:10.1016/0269-7491(93)90015-G

[15] A. E. Soto-Rojas, J. L. Ureña-Cirett and E. A. MartínezMier, "A Review of Prevalence of Dental Fluorosis in Mexico," Revista Panamericana de Salud Pública, Vol. 15 No. 1, 2004, pp. 9-18. doi:10.1590/S1020-49892004000100003

[16] A. P. Pontigo-Loyola, C. E. Medina-Solís, E. Lara-Carrillo, N. Patiño-Marín, M. Escoffié-Ramirez, M. MendozaRodríguez, R. De La Rosa-Santillana and G. Maupomé. "Impact of Socio-Demographic, Socioeconomic, and Water Variables on Dental Fluorosis in Adolescents Growing Up during the Implementation of a Fluoridated Domestic Salt Program," Odontology, 2013, in Press.

[17] A. García-Pérez, M. E. Irigoyen-Camacho and A. BorgesYáñez, "Fluorosis and Dental Caries in Mexican Schoolchildren Residing in Areas with Different Water Fluoride Concentrations and Receiving Fluoridated Salt," Caries Research, Vol. 47, No. 4, 2013, pp. 299-308. doi: $10.1159 / 000346616$

[18] A. D. Eaton, L. S. Clesceri, A. E. Greenberg and M. A. Franson, "Standard Methods for Examination of Water \& Wastewater," American Public Health Association, Washington DC, 2005.

[19] W. G. Kohn, J. A. Harte, D. M. Malvitz, A. S. Collins, J. L. Cleveland and K. J. Eklund, "Centers for Disease Control and Prevention: Guidelines for Infection Control in Dental Health Care Settings-2003," Journal of the American Dietetic Association, Vol. 135, No. 1, 2004, pp. 3347.

[20] A. Thylstrup and O. Fejerskov "Clinical Appearance of Dental Fluorosis in Permanent Teeth in Relation to Histologic Changes," Community Dentistry and Oral Epidemiology, Vol. 6, No. 6, 1978, pp. 315-328. doi:10.1111/j.1600-0528.1978.tb01173.x

[21] World Health Organization, "Oral Health Survey-Basic Methods," 4th Edition, WHO, Geneva, 1997.

[22] C. Fries, "Geología del Estado de Morelos y de Partes Adyacentes de México y Guerrero, Región Central Meridional de México," Boletín 60 Instituto de Geología, Mexico, 1960, pp. 236.

[23] K. Kim and S. T. Yun, "Buffering of Sodium Concentration by Cation Exchange in the Groundwater System of a Sandy Aquifer," Geochemical Journal, Vol. 39, No. 3, 2005, pp. 273-284. doi:10.2343/geochemj.39.273 
[24] G. T. Chae, S. T. Yun, K. Kim and B. Mayer, "Hydrogeochemistry of Sodium-Bicarbonate Type Bedrock Groundwater in the Pocheon Spa Area, South Korea: Water-Rock Interaction and Hydrologic Mixing," Journal of Hidro-geology, Vol. 321, No. 1-4, 2006, pp. 325-343.

[25] G. T. Chae, S. T. Yun, B. Mayer, K. H. Kim, S. Y. Kim, J. S. Kwon, K. Kim and Y. K. Kohn, "Fluorine Geochemistry in Bedrock Groundwater of South Korea," Science of the Total Environment, Vol. 385, No. 1-3, 2007, pp. 272283. doi:10.1016/j.scitotenv.2007.06.038

[26] T. Rafique, S. Naseem, T. H. Usmani, E. Bashir, F. A. Khan and M. I. Bhanger, "Geochemical Factors Controlling the Occurrence of High Fluoride Groundwater in the Nagar Parkar Area, Sindh, Pakistan," Journal of Hazardous Materials, Vol. 171, No. 1-3, 2009, pp. 424-430. doi:10.1016/j.jhazmat.2009.06.018

[27] J. J. Carrillo-Rivera, A. Cardona and W. M. Edmunds, "Use of Abstraction Regime and Knowledge of Hydrogeological Conditions to Control High-Fluoride Concentration in Abstracted Groundwater: San Luis Potosí basin, Mexico," Journal of Hydrology, Vol. 261, No. 1-4, 2002, pp. 24-47. doi:10.1016/S0022-1694(01)00566-2

[28] A. K. Adelário, L. F. Vilas-Novas, L. S. Castilho, A. M. Vargas, E. F. Ferreira and M. H. Abreu, "Accuracy of the Simplified Thylstrup \& Fejerskov Index in Rural Communities with Endemic Fluorosis," International Journal of Environmental Research and Public Health, Vol. 7, No. 3, 2010, pp. 927-937. doi:10.3390/ijerph7030927

[29] A. Tsutsui, M. Yagi and A. M. Horowitz, "The Prevalence of Dental Caries and Fluorosis in Japanese Communities with Up to $1.4 \mathrm{ppm}$ of Naturally Occurring Fluoride," Journal of Public Health Dentistry, Vol. 60, No. 3, 2000, pp. 147-153. doi:10.1111/j.1752-7325.2000.tb03320.x

[30] C. E. Medina-Solis, A. P. Pontigo-Loyola, G. Maupome, H. Lamadrid-Figueroa, J. P. Loyola-Rodríguez, J. Hernández-Romano, J. J. Villalobos-Rodelo and M. de Lourdes Marquez-Corona, "Dental Fluorosis Prevalence and Severity Using Dean's Index Based on Six Teeth and on 28 Teeth," Clinical Oral Investigations, Vol. 12, No. 3, 2008, pp. 197-202. doi:10.1007/s00784-007-0171-7

[31] M. L. Azpeitia-Valadez, M. Rodríguez-Frausto and M. A. Sánchez-Hernández, "Prevalence of Dental Fluorosis in Children between 6 to 15 Years Old," Revista Médica del Instituto Mexicano del Seguro Social, Vol. 46, No. 1, 2008, pp. 67-72.

[32] Norma Oficial Mexicana, NOM-127- SSA1-1994, "Salud
Ambiental, Agua Para Uso y Consumo Humano. Limites Permisibles de Calidad y Tratamientos a Que Debe Someterse el Agua Para su Potabilización," Diario Oficial de la Federación, Secretaría de Salud, Mexico, 2000, pp. $1-7$.

[33] Environmental Protection Agency (EPA), 2011. http://water.epa.gov/action/advisories/drinking/fluoride i ndex.cfm

[34] A. P. Pontigo-Loyola, A. Islas-Márquez, J. P. LoyolaRodríguez, G. Maupome, M. L. Marquez-Corona and C. E. Medina-Solis, "Dental Fluorosis in 12- and 15-YearOlds at High Altitudes in Above-Optimal Fluoridated Communities in Mexico," Journal of Public Health Dentistry, Vol. 68, No. 3, 2008, pp. 163-166. doi:10.1111/j.1752-7325.2007.00065.x

[35] M. E. Irigoyen, N. Molina and I. Luengas, "Prevalence and Severity of Dental Fluorosis in a Mexican Community with Above-Optimal Fluoride Concentration in Drinking Water," Community Dentistry and Oral Epidemiology, Vol. 23, No. 4, 1995, pp. 243-245. doi:10.1111/j.1600-0528.1995.tb00239.x

[36] R. Hurtado and J. Gardea-Torresdey, "Environmental Evaluation of Fluoride in Drinking Water at 'Los Altos de Jalisco', in the Central Mexico Region," Journal of Toxicology and Environmental Health, A, Vol. 67, No. 20-22, 2004, pp. 1741-1753. doi:10.1080/15287390490493448

[37] M. A. Armienta and N. Segovia, "Arsenic and Fluoride in the Groundwater of Mexico," Environmental Geochemistry and Health, Vol. 30, No. 4, 2008, pp. 345-353. doi:10.1007/s10653-008-9167-8

[38] M. Grimaldo, V. H. Borja-Aburto, A. L. Ramírez, M. Ponce, M. Rosas and F. Díaz-Barriga, "Endemic Fluorosis in San Luis Potosi, Mexico. I. Identification of Risk Factors Associated with Human Exposure to Fluoride," Environmental Research, Vol. 68, No. 1, 1995, pp. 25-30. doi:10.1006/enrs.1995.1004

[39] C. M. Rwenyonyi, J. M. Birkeland, O. Haugejorden and K. Bjorvatn, "Age as a Determinant of Severity of Dental Fluorosis in Children Residing in Areas with 0.5 and 2.5 mg Fluoride per Liter in Drinking Water," Clinical Oral Investigations, Vol. 4, No. 3, 2000, pp. 157-161. doi:10.1007/PL00010677

[40] C. M. Marya, B. R. Ashokkumar, S. Dhingra, V. Dahiya and A. Gupta, "Exposure to High-Fluoride Drinking Water and Risk of Dental Caries and Dental Fluorosis in Haryana, India," Asia-Pacific Journal of Public Health, 2013, in Press. 